\title{
His束ペーシングの臨床応用
}

\begin{tabular}{lllllll}
\multicolumn{8}{c}{ 京都第一赤十字病院第二内科 } & \\
望月 茂 & 桐山 & 利昭 & 角水 & 圭一 & 和田 勝 \\
和多田光朗 & 礒田 & 次雄 & 川西 & 康夫 & 水谷 孝昭
\end{tabular}

\section{CLINICAL USE OF HIS BUNDLE PACING}

Shigeru Mochizuki, M.D., Toshiaki Krriyama, M.D., Keiichi Kakusur, M.D., Masaru WADA, M.D., Mitsuro WATAda, M.D., Tsuguo Isoda, M.D., Yasuo Kawanssh, M.D. and Takaaki Mizutan, M.D.

The Second Department of Internal Medicine, Kyoto First Red Cross Hospital, Kyoto

\begin{abstract}
概要 His束心電図記録に際して重要なことは,His束電位(H)のvalidationである.とくにHis-Purkinje 系の伝導時間（HV）の定量的測定にはHのvalidationが必須である．Hのvalidationの方法としてHis 束ペーシングが有用である．HとR B (右脚電位) の鑑別，His束内プロック時の $\mathrm{H}^{\prime}$ (distal H)と R B の鑑別炕はHis束ペーシングが有力である。われるれは左軸倔位を伴う右脚プロック（R B B B + L A D） 4 例，房室ブロック 6 例，His束内ブロック 1 例, Wolff-Parkinson-White (WPW) 症候群 8 例 を含さ30例でHis束心電図記録と同時にHis束ペーシングを行ない，その有用性を確認した，正常者群 ではHis束ベーシング中，刺激波から体表面心電図のQR S の始まり迄（St-R）は正常洞調律時 また は心房ペーンング時のHV時間に等しかった，同時記録した体表面心電図のすべての誘導でQR S 形，大きさ，持続時間は洞調律時と全く同しで变化しなかつた．His-Purkinje間の伝導時間（St-R） はHis束ペーシングのレートをかえても变化しなかつた，R B B B + L A D 4 例の内, 洞調律時にH V の延長家認めた 2 例では，His束ベーシングのレート增加によりSt-Rは延長した。これは両脚ブロッ クを示唆する所見である，WPW店候群 8 例の内，いわゆるKent束の 7 例ではHis束ペーシング時の QR S はデルタ波を伴わず正常伀導型のQR S を示した，又，他の1例でHis束ペーシング時のQ R SはWPWパターンを示しいわゆるMahaim束の存在が示唆された。
\end{abstract}

\section{緒言}

His束心電図記録法といら簡単で安全な方法が 導入されて以来 ${ }^{122)}$ ，刺激伝導系の研究に大いに 役立ち，従来の体表面心電図から得られる情報を 大いに拡大したといえる。His束電位 $(\mathrm{H})$ と右 脚電位（R B ）をHis束心電図上で鑑別すること は必ずしも容易でないことがあり，その昜合Hの

〔昭和50年 9 月 18 日受稿】

本論文の要旨红第39回日本循環器学会総会(1975年

4 月，京都市）にて発表した。
validationにはHis束ペーシングが有用で市る。 His束ペーシングにかんしてはイヌによる実験的 研究 ${ }^{334)}$ の他に臨床的にはNarula $5^{576)}$ の研究があ るのみである。われわれは各種伝導障害を有する 症例, 有しない症例和よびWolff-Parkinson-White (WPW) 症候群など計30例に扎いて, His束心電 図記録と同時にHis束ペーシングを行ない，その 有用性を確認した。

\section{対象および方法}

対象は左軸偏位を伴ら右脚ブロック4例, 房室 
ブロック 6 例, 脚ブロック 3 例, His束内ブロッ ク 1 例，WPW症候群 8 例を含む30例で年令は 8 才から79才论である. His束心電図記録はScherlag ら"の方法によつた．電極間隔 $10 \mathrm{~mm}$ の双極カテー テルを右大伏在静脈より挿入し，透視下に三尖弁 の中隔尖をこえた所でHis束電位 (H) が最もよ く記録される所に拈いた。ささらにもう1本の双極 カテーテルを同じ血管から挿入し心房ペーシング 用に用いた．His束電位は40〜 500Hzで記録 し た. 記録は日本光電 6 チャンネルの写真式ポリコ ーダーを用い，紙送り速度 $100 \mathrm{~mm} / \mathrm{sec}$ で記録し た。まずAH (His束心電図の心房の興奮の始まり からHis束電位の始まりまで)，およびHV(His束 電位の始まりからHis束心電図上の心室の興奮の 始まり迄）の間隔を測定し，さらに心房ペーシン グによるこれらの間隔の変化を調べた．次にHis 束心電図記録に用いた双極カテーテルを体外式ぺ ースメーカーに接続し，His束ペーシングを行な つた. His束ペーシングは，少なくとも心房ペー シング時の最大ペーシングレート以上迄レートを あげて記録した。一方心房の双極カテーテルは心 房の電位記録用に用いた。また，体表面心電図の 2 誘導を同時に記録した。

\section{結 果}

刺激伝導障害を 伴わない 8 例では，His束ペー シング中刺激波からQR S の始まり迄の間隔（以 下St-Rと略す）は，洞調律時または心房ペーシ グ時のH V間隔に等しかつた. 同時記録した体表 面心電図のすべての誘導でQR S の形, 大きさ, 持続時間は，洞調律時 と全く同じで変化しなか つた. His-Purkinje間の伝導時間 (St-R) はHis束 ペーシングのレートをかえても変化しなかつた。

症例 1 : 図 1 に刺激伝導障害を伴わない症例 の 1 例を示す.この症例を含めてHis束ペーシン グ中心房とHis束が同時に刺激される場合が多か つた。

次に左軸偏位を伴ら右脚ブロックの症例 4 例の らち 2 例では, 洞調律時にHV間隔は正常で, か っHis束ペーシングのペーシングレートをあげて

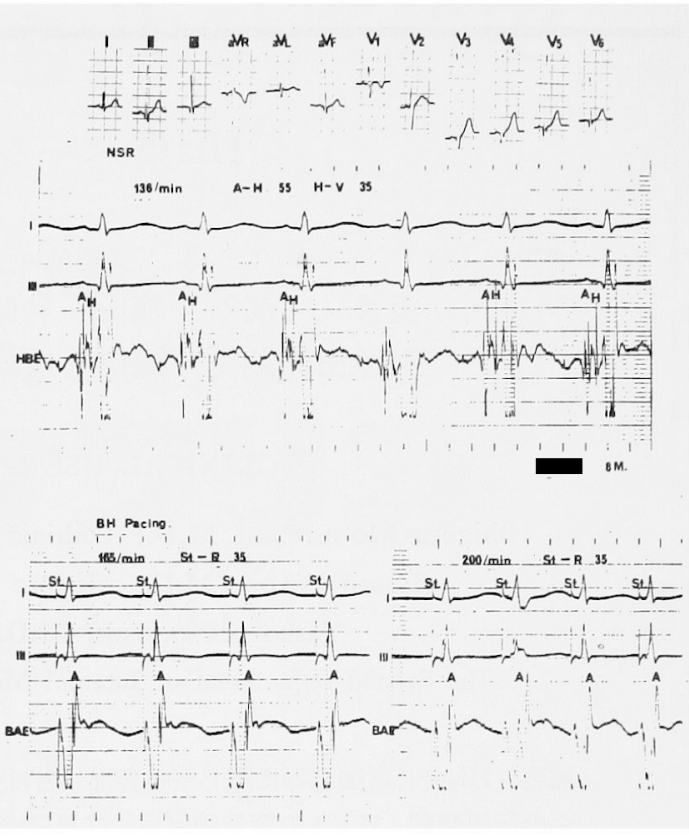

図 1，症例 1（8才，男子）上段の体表面心電図か 示す様に正常例である。 中段のよ5に 136/分 の洞 調律時 A H 55msec, HV 35msec と正常範囲内にあ る.下段のよ5にHis 束ベーシングでレートを 165/ 分, 200/分と增加させてもSt-Rは $35 \mathrm{msec}$ と洞調律 時のHV間隔に等しく变化しなかつた。， 又，His束 ペーシングのレートをかえてる体表面心電図の Q R S の大きさ, 形, 持続時間は洞調律時と全く同し で変化しなかつた。

むSt-Rは洞調律時の H V 間隔に 等しく延長しなか つた． 4 例のうち他の 2 例では洞調律時からすで にH V 間隔は延長し,His束ぺーシングのレート増 加によりSt-Rが延長した．両脚ブロックを示唆す る所見である．前者および後者の各 1 例を示す.

症例 2 (図 2)：75才，女子, 右脚ブロッ ク, 左軸偏位の症例で, 60/分の正常洞調律を示 している時はAH110msec, HV 50msecであり， 正常值を示している. 心房ペーシングでレートを 増加させると，160/分でA H間のWenckebach型 ブロックを生じた．その時のH V間隔は50msec であり, 洞調律時のHV間隔に等しかつた，次に His束ペーシングを行ないレートを 185/分迄増加 させてもSt-Rは $50 \mathrm{msec}$ と洞調律時のH V 間隔に等 しく変化しなかつた。 


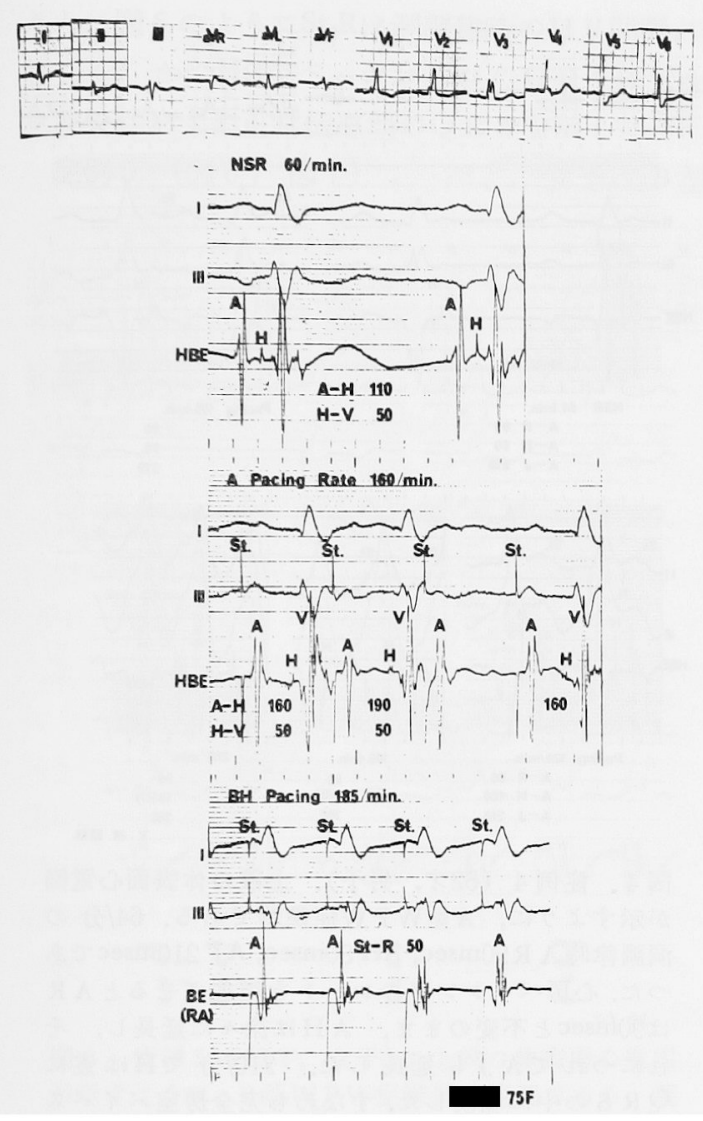

図2，症例 2（75才，女子）。上段の体表面心麗図 は右脚ブロック，左軸偏位を示している。60/分の 正常洞調律を示している時, AH $110 \mathrm{msec}, \mathrm{HV} 50$ $\mathrm{msec}$ と正常值を示している。 心房ペーシングでレ 一トを增加させると 160/分でAH間のWenckebach

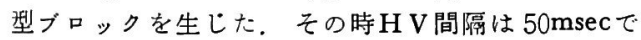
洞調律時の $\mathrm{HV}$ V等しかつた。次にHis束ペーンン グでレートを185/分迄增加させても，St-Rは $50 \mathrm{msec}$ と洞調律時の $\mathrm{HV}$ 間隔に等しからた。

症例 3 （図 3 ）：67才, 男子. 右脚ブロック， 左軸偏位の症例で, 洞調律時 A H $110 \mathrm{msec}$ と 正常であるがH Vは70msec と延長していた。本 症例ではHis束ペーシング時に心房とHis束が同時 に刺激され，そのためにHis束ペーシング時に QR S の始まりを同定することは難 しかつた。 したがつて，比較的QR S の始まりのはつきりし ている第 I 誘導の R の立上り (RI) をQ R S の始 まりとして用いた，洞調律時 $\mathrm{H} か ら$ 第 I 誘導の

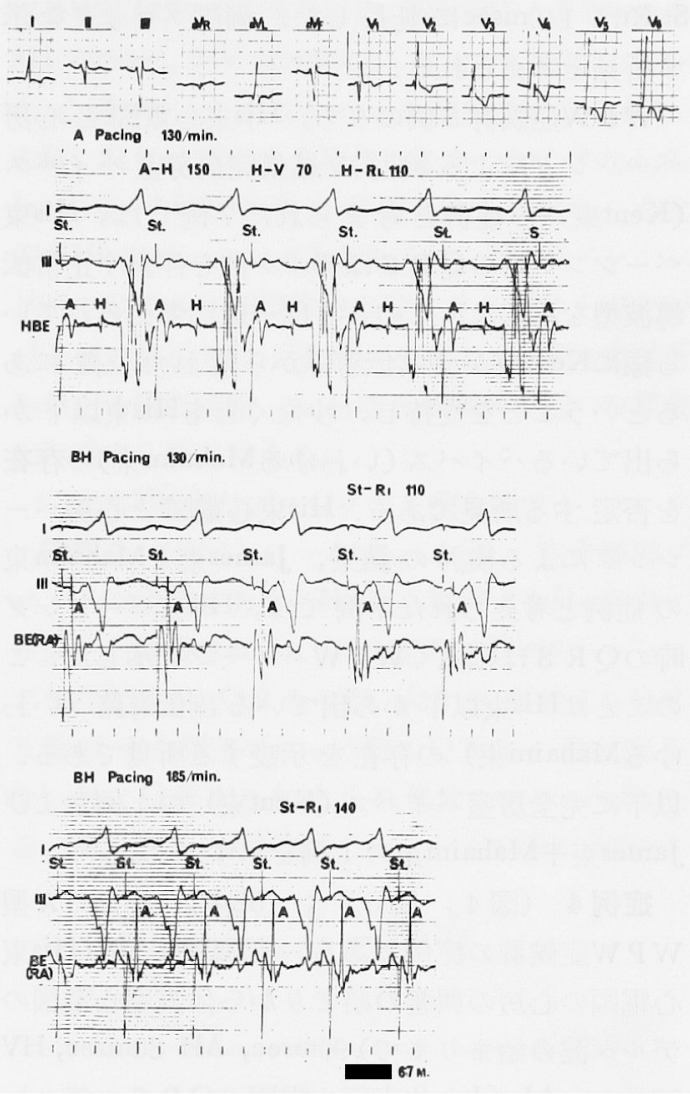

图 3。症例 3（67才，男子）。上段の体表面心電図 が示すよ5に，右脚ブロック十左軸偏位の症例であ る。洞調律時および $130 /$ 分 の心房ベーシング時 $\mathrm{H}$ V $70 \mathrm{msec}$ と延長していた。本症例では, His束べー シング時に心房とHis束が同時に刺激され，そのた めにQR S の始まりを同定することが困難であつ た。 そのために比較的QR S の始まりのはつきりて ている第 I 誘導の R の立上り $(\mathrm{RI})$ を $\mathrm{QR} \mathrm{S}$ の始 まりとして用いた。洞調律時および 130/分の心

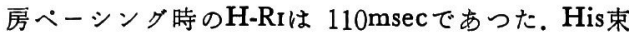
ペーシンダを行ならと130/分ではSt-RIは110msec であつたが、ペーシングレートを185/分迄增加ざ せるとSt-RIは $140 \mathrm{msec}$ 迄延長した。両脚ブロック を示す所見と考えられる。

Rの立上り迄 (H-RI) は110msecで，130/分の心 房ペーシング時 のH-Rr \& $110 \mathrm{msec}$ 変化しなか つた. 次にHis束ペーシングを行ならと、ペーシ ングレート 130/分ではSt-RIは 110msecであつた が，ペーシングレートを185/分迄増加させると 
St-RIは 140msecに 延長 した。両脚ブロックを示 す所見と考㝋られる。

W P W症候群 8 例のうち, His束心電図 と心房 ペーシングによる検討 の結果完全房室バィパス （Kent束）の症例と考克られた 7 例では，His束 ペーシング時のQR S はデルタ波を伴わず正常伝 導波型を示した。このことは一般に考えられてい る様にKent束が正常伝導系から離れた位置にあ るということを支持し，少なくともHis束以下か ら出ているバィパス(いわゆるMahaim束)の存在 を否定する所見である. His束心電図 と心房ペー シングによる愉討の結果, James束+Mahaim束 の症例と考兄られた 1 例では, His束ぺーシング 時のQR S は幅広くW P W パターンを示した。こ のことはHis束以下から出ている副伝導路（いわ ゆるMahaim束）の存在を示唆する所見である． 以下に完全房室バィパス (Kent束) の 1 例岾よび James束+Mahaim束の 1 例を示す.

症例 4 （図 4, 図 5)：52才, 男子. A 型 W P W症候群の症例である．洞調律時AR (His束 心電図の心房の興奮の始まりから体表面心電図の デルタ波の始まりまで) 90msec, $\mathrm{AH} 80 \mathrm{msec}, \mathrm{HV}$ $55 \mathrm{msec}, \mathrm{AJ}$ (Jは体表面心電図のQR S の終り) 210msecであつた。 心房ペーシングでレートを 増加させると, A Rは90msec と不変のまま, A H は徐々に延長し，それにつれてA J あ延長した。

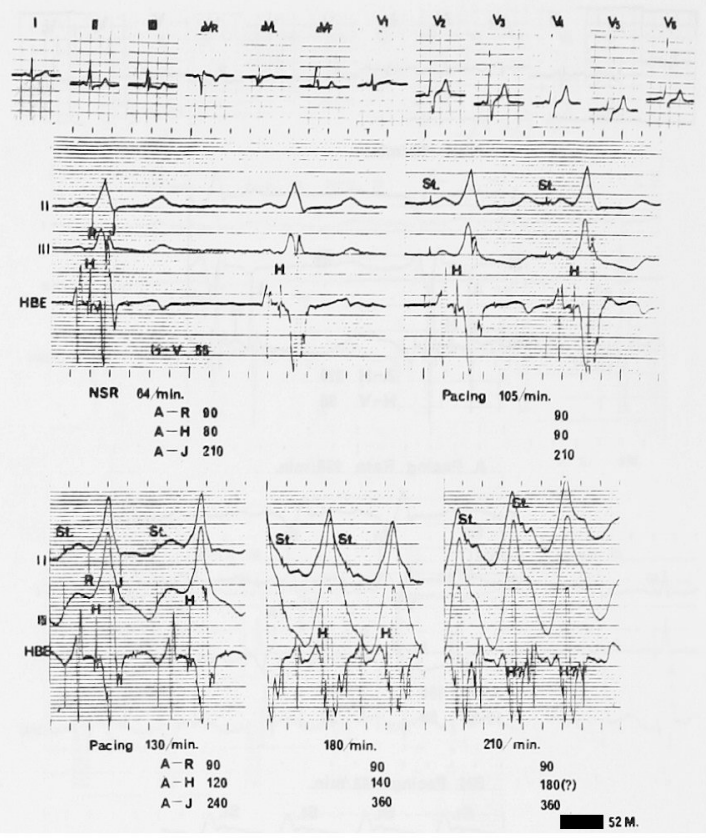

図 4.症例 4（52才，男子）。上段の体表面心電図 が示すように，A 型W P W 症候群である.64/分の 洞調律時 A R 90msec, AH 80msec, AJ 210msecであ つた. 心房ペーシングのレートを增加させると A R は90msec と不変のまま，A Hは徐々に延長し，そ れにつれてA J 延長した。 210/分でHは遂に QR S の中に埋没した。すなわち完全房室バイパス （Kent束）の症例と考えられる.

すなわち完全房室バィパス (Kent束) の症例と 考えられる.この症例でHis束ペーシングを行な

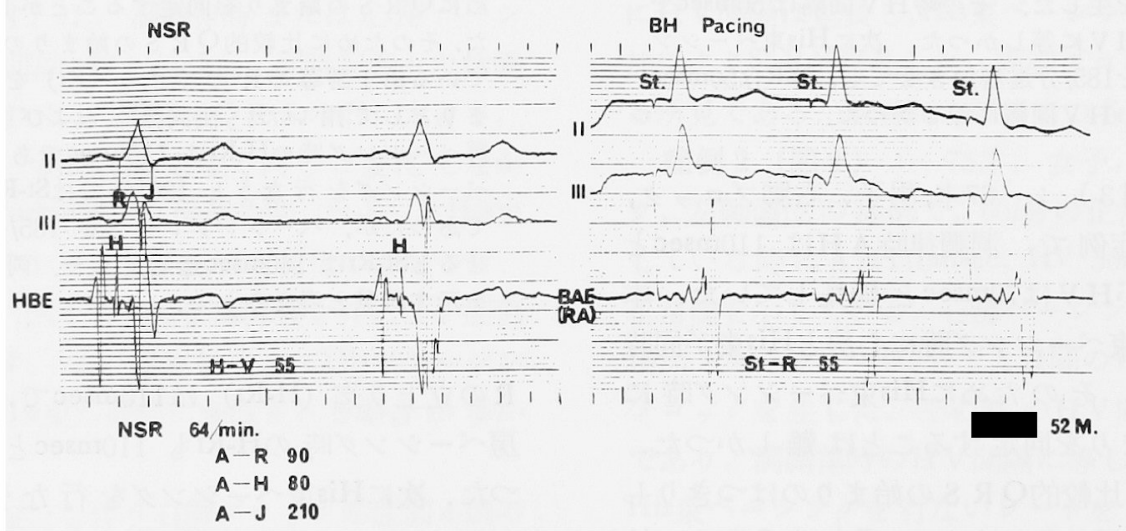

因 5 。症例 4 (52才男子)His束ベーシングを行な 5 と St-Rは 洞調律時 のH V間隔に等しく, かつHis束ペーシング中の G R S はデルタ波を伴わず正常伝導型のQR S を示した. 
らと, 因 5 のようにSt-Rは洞調律時のH V 間隔に 等しく，かつHis束ペーシング中のQR S はデル タ波を伴わず，正常伝導型のQR S を示した. 症例 5 (図6, 図7）：23才，女子， B 型

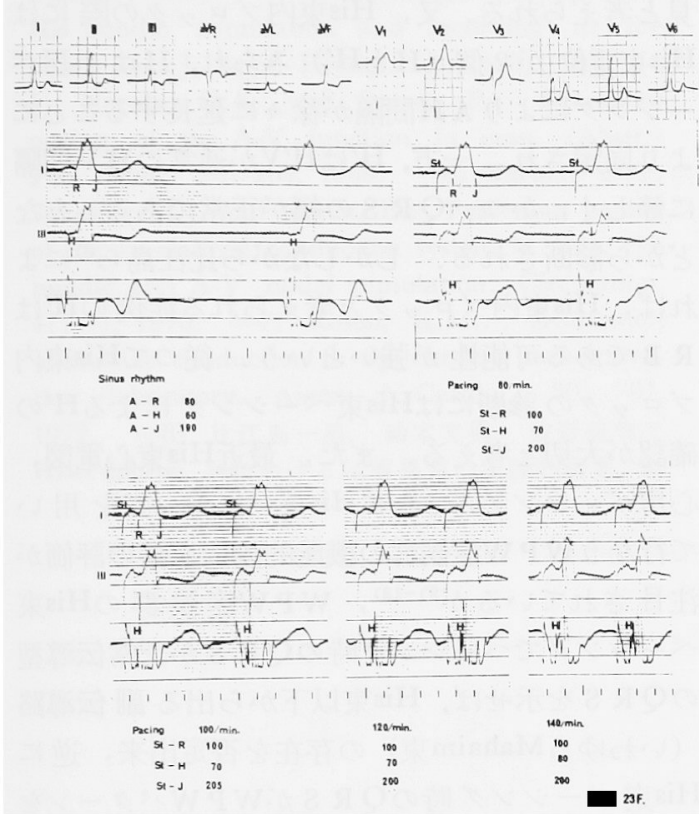

図 6. 症例 5 (23才，女子). 上段の体表面心電図 が示すように，B 型W P W 症候群の症例である. 洞 調律時 A R 80msec, AH 60msec, HV25msec といず れも短樎していた。房ベーシングでベーシングレ 一トを增加させると A R, A H， H V は短いまま变 化しなかつた。すなわちJames束+Mahaim束の症 例と考えられる。

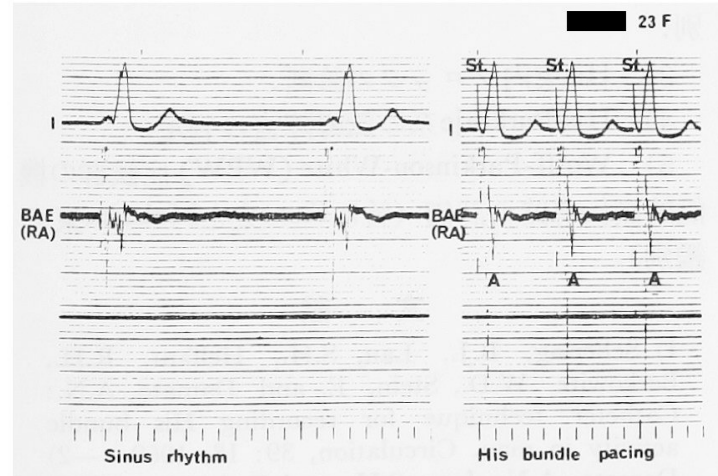

図 7. 症例 5（23才，女子). His束ペーシングを行 ならと，His束ベーシング時のQR S は洞調律時の QRSと同じくW PWパターンを示した.
W P W症候群の症例である.洞調律時 A R $80 \mathrm{msec}$, $\mathrm{AH}$ 60msec, HV 25msecといずれ す短縮 してい た.心房ペーシングでレートを増加させてる A R， A H，HVは短いまま変化しなかつた。すなわち James束十Mahaim束の症例と考元られる. 本症 例でHis束ペーシングを行ならと, His束ペーシン グ時のQR S は洞調律時のQR S と同じく W P W パターンを示した（図７）.このことはHis束以下 から出る副伝導路（いわゆるMahaim束）の存在 を示唆する所見である。

次にHis束内ブロックの 1 例を示す.

症例 6 （図 8）：64才，女子. 完全房室プ ロックの症例である. His束心電図よりHis束内プ ロックと診断される.この症例でHis束ペーシン グを行なうと，QR S の形，大きさ，幅およびQ R $\mathrm{S}$ 軸は完全房室ブロック時のQR S と殆ど変ら ないが，QR Sの始まりの部分にスラーを認め る.このスラーがHis束ペーシングの際に刺激が
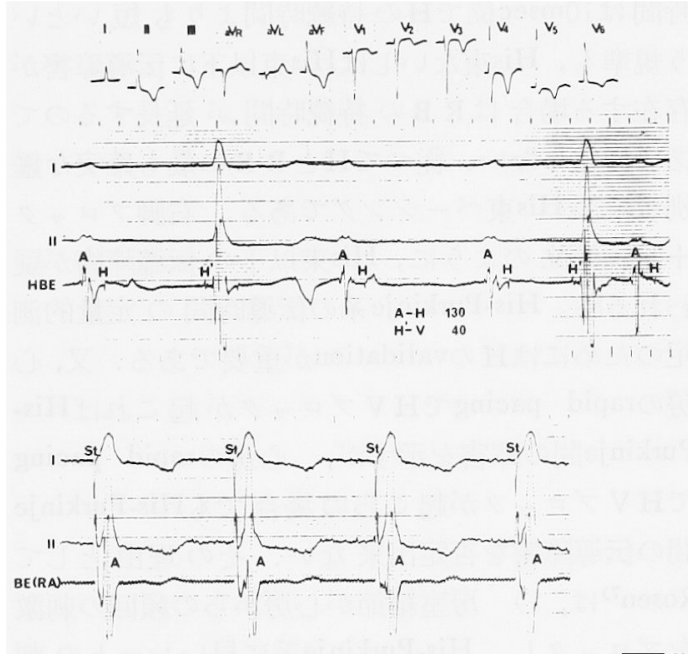

図 8，症例 6（64才，女子），完全房室ブロックの 症例であるが，図の中段に示すHis束心電図より His束内ブロックと診断される。本症例でHis束へ ーシングを行な5と下段の様にQR S の形，大き さ，幅およびQ R S 軸は完全房室ブロック時の $\mathrm{Q}$ R S と殆ど変らないが，QR S の始まりの部分にス ラーを認め下波の变形むみられることより心室べ ーシングの可能性が強い。すなわちHis束ペーシン グの不成功例と考えられる. 
septumに流れたためか，右脚ないし右心室起始 部を刺激したためかの区別が問題になる。いずれ にしろ T波の変形もみられることより心室ペーシ ングの可能性が強い，すなわちHis束ペーシング の不成功例之考光られる。

\section{考案}

His束心電図記録に際して重要なことはHis束 電位 $(H)$ ovalidationである，房室結節電位（N), His束電位 (H)，右脚電位（R B）はいずれも体 表面心電図のP R 間隔の間に記録されるために三 者の鑑別が必要になる，H， R B と Nの鑑別は比 較的容易である。といらのは房室結節電位 $(\mathrm{N})$ は 持続時間が長く(50msec)，ふれも小さいからであ る．ところがHis束電位（H）と右脚電位（R B ） は心房ペーシングに際し同様の反応を示す。すな わち心房ペーシングのペーシングレート增加に 伴いAH，A-RBは徐々に，そして著明に延長する。 また，一般にいわれているよらに， R Bの持続 時間は10msec位でHの持続時間よりも短いとい ら規準も，His束ないしはHis束以下に伝導障害が 存在する場合は R Bの持続時間が延長するので あてにならない，従つて 別手段はHis束ぺーシングである。右脚プロック 十左軸偏位の上らに, His束以下の伝尊障害が疑 われる時, His-Purkinje系の伝導時間の定量的測 定のためにはHのvalidationが重要である，又，心 房のrapid pacingでHVブロックが起こればHisPurkinje間の障害を示すが，心房のrapid pacing でHVブロックが起こら奴場合でもHis-Purkinje 間の伝導障害を否定出来ない，その理由として Rosen ${ }^{72}$ は，1） 房室結節が心房からの頻回の刺激 をブロックし，His-Purkinje系に早いレートの刺 激が伝わるのを防いでいる，2） His-Purkinje系 はある時には早いレートのインパルスを通すが， 時には通さないことがあると述べている。徒つ て心房ペーシングではAH間でのブロックのため にrapid pacingに対するH V間隔の反応を知るこ とは困難である．His束ペーシングでは房室結節 でブロックされないので，心房ペーシング以上の rapid pacingに対するHV間隔の反応をみること が可能である。われわれは，症例 3 に沶いてHis 束ペーシングのペーシングレート増加によりSt-R の延長をみた。すなわち両脚ブロックを示す所 見と考えられる．又，His束内プロックの際には His束電位が 2 個 $\left(\mathbf{H} と H^{\prime}\right)$ みられ，Hは心房へ ーシングにより A H間隔が徐々に延長することに より同定され，一方， $\mathrm{H}^{\prime} は \mathrm{H}^{\prime} \mathrm{V}$ 通常のH V 間隔 飞等しく，かつ，QR S の幅が正常であることな どから診断される。しかしながら比江島ら゙によ れば，His束内ブロックと考交られる症例のH出 R Bである可能性が強いという，従つてHis束内 ブロックの詪断にはHis束ペーシングによるH'の 確認加大切と考える。 また，最近His束心電図， 心房ペーシング，さらにHis束ペーシングを用い て行なら W P W症候群の機能的副伝導路の評価が 注目されているが92 18)，W P W症候群のHis束 ペーシングでペーシング時のQR S が正常伝導型 のQR S を示世ば，His束以下から出る副 伝導路 （いわゆるMahaim束）の存在を否定出来，逆に His束 ペーシング時のQ R S がW P Wパターンを 示せばMahaim束の存在が示唆される。

\section{まとめ}

His束ぺーシングの臨床応用としては次の様な ものがあげられる。

1）His束電位 $(\mathrm{H})$ のvalidation.

2) His束電位 (H) と右脚電位 (R B ) の鑑 別.

3） His束内ブロックの彰断.

4）His-Purkinje系の伀導障害の判定.

5) Wolff-Parkinson-White (WPW) 症候群の機 能的副伝導路の評価（特にKent束とMahaim束の 鑑別).

\section{文献}

1) Scherlag, B.J., Lau, S.H., Helfant, R.H., Berkowitz, W.D., Stein, E. and Damato, A.N.: Catheter technique for recording $\mathrm{His}$ bundle activity in man. Circulation, 39: 13, 1969. -2) Damato, A.N., Lau, S.H. and Berkowitz, W.D.: Recording of specialized conducting fibers (A-V node, His bundle and right bundle branch) in man using an electrode catheter technique. 
Circulation, 39: 435, $1969 . \quad-3)$ Scherlag, B.J., Kosowsky, B.D. and Damato, A.N.: A technique for ventricular pacing from the His bundle of the intact heart. J. Appl. Physiol. 22: 584, 1967. -4) Scherlag, B.J., Helfant, R.H. and Damato, A.N.: A catheterization technique for His bundie stimulation and recording in the intact dog. J. Appl. Physiol. 25: 428, 1968. 5) Narula, O.S. and Samet, P.: Pervenous pacing of the A-V junction in man. (Abstr.) Fed. Proc. 28: 269, 1969. -6) Narula, O.S., Scherlag, B.J. and Samet, P.: Pervenous pacing of the specialized conduction system in man. His bundle and A-V nodal stimulation. Circulation, 41: 77, 1970. -7) Rosen, K.M.: Evaluation of cardiac conduction in the cardiac catheterization laboratory. Amer. J. Cardiol., 30: 701, 1972. -8) 比江島一昌，鉿木文男，佐野豐美： His-Purkinje 系に打ける伝導異常の実驗的研究. 第
38回日本循環器学会総会講演, 1974. 一9) Castellanos, A., Chapunoff, E., Castillo, C., Maytin, O. and Lemberg, L.: His bundle electrograms in two cases of Wolff-Parkinson-White (Preexcitation) syndrome. Circulation, 399, 41: 1970. -10) Castellanos, A., Castillo, C.A. and Agha, A.S.: Contribution of $\mathrm{His}$ bundle recordings to the understanding of clinical arrhythmias. Amer. J. Cardiol., 28: 499, 1971. -11) Smithen, C.S. and Krikler, D.M.: Aspects of pre-excitation and its elucidation by $\mathrm{His}$ bundle electrograms. Brit. Heart J., 34: 735, 1972. -12) 望月 茂, 角水圭一，桐山利昭，和田 勝，高橋邦子，碚田 次雄，近藤晴彦，水谷孝昭: W P W 症候群の His 束心電图に上る検討。心葴，5：1402，1973，一13) 望月 茂, 水谷孝昭, 桐山利昭: W P W 症候群の上 ス束エレクトログラム，呼吸と循環，22:393， 1974 . 